\title{
Desain Kapal Pembangkit Listrik Menggunakan Tenaga Gelombang Air Laut Untuk Daerah Papua
}

\author{
Bimo Taufan Devara, Wasis Dwi Aryawan, dan Ahmad Nasirudin \\ Departemen Teknik Perkapalan, Fakultas Teknologi Kelautan, Institut Teknologi Sepuluh Nopember \\ (ITS) \\ e-mail: anasirudin@gmail.com
}

\begin{abstract}
Abstrak - Kondisi kelistrikan di Indonesia belum merata, bahkan untuk wilayah Indonesia bagian tengah dan timur, pasokan listrik masih jauh dari cukup. Kondisi ini disebabkan karena beberapa hal, yang salah satunya adalah kurang meratanya pembangunan pada daerah-daerah Indonesia bagian tengah dan timur . Papua adalah provinsi yang memiliki tingkat elektrifikasi terendah di Indonesia di mana dari keseluruhan wilayahnya hanya $47 \%$ yang sudah teraliri listrik. Dalam Studi ini akan didesain kapal pembangkit listrik dengan tenaga gelombang air laut sebagai unit pembantu khususnya pada Kota Serui. Pengerjaan diawali dengan mencari kebutuhan listrik yang ideal dari Kota Serui, yaitu sebesar 8,4 MW. Daya yang telah terpasang adalah 5,6 MW sehingga kekurangan daya adalah sebesar 2,8 MW. Berikutnya dipilih alat-alat pembangkit listrik tenaga gelombang air laut, yaitu floats, inverter dan baterai. Dibutuhkan dua buah kapal untuk memenuhi seluruh kebutuhan listrik Kota Serui karena membutuhkan waktu pengisian energi. Dengan pengisian selama 9 jam, masing-masing kapal menggunakan 18 baterai dengan daya sebesar 2 MW dan 20 floats dengan daya sebesar 0.2 MW. Secara total, satu kapal menghasilkan energi sebesar 36 MWh. Ukuran Utama Kapal yang didapatkan adalah $\mathrm{L}=95,89 \mathrm{~m}, \mathrm{~B}=18,5 \mathrm{~m}, \mathrm{H}=\mathbf{5 , 2} \mathrm{m}, \mathrm{T}=$ $3,75 \mathrm{~m}$.
\end{abstract}

Kata Kunci-kapal pembangkit listrik, tenaga gelombang air laut, Papua, Kota Serui.

\section{PENDAHULUAN}

$\mathrm{P}$ APUA adalah daerah dengan pembangunan yang paling tertinggal di Indonesia. Tantangan terbesar dalam melistriki wilayah Papua diantaranya adalah terbatasnya infrastruktur transportasi yang menyebabkan tingginya biaya operasi seperti biaya angkut bahan bakar yang jauh lebih besar dari harga rupiah per kilo watt hour. Disamping itu, kondisi geografis yang berupa hutan dan pegunungan juga menjadi alasan sulitnya akses kelistrikan. Di Papua, terdapat 14 kota/ kabupaten dengan 110 desa yang belum berlistrik sama sekali. Selain 110 desa tersebut, masih banyak desa-desa dan daerah pelosok yang listriknya hanya hidup enam jam, delapan jam dan 12 jam. Semuanya hanya hidup dibawah 24 jam. (BBC Indonesia, 2016). Berdasarkan survei yang dilakukan oleh Badan Pengkajian dan Penerapan Teknologi (BPPT) dan pemerintah Norwegia sejak tahun 1987, terdapat banyak daerah di Indonesia yang berpotensi sebagai sumber tenaga gelombang air laut, diantaranya adalah sepanjang pantai selatan Pulau Jawa, laut di sekitar Pulau Sumatera dan laut di sekitar Pulau Papua. Tinggi gelombang laut yang dianggap potensial untuk menjadi pembangkit listrik adalah $1,5 \mathrm{~m}$ sampai $2 \mathrm{~m}$ dan gelombang tersebut tidak pecah sampai daerah pantai. Berdasarkan data-data tersebut, penggunaan tenaga gelombang air laut sebagai sumber tenaga listrik akan menjadi solusi yang efektif apabila di aplikasikan pada daerah Papua mengingat laut pada daerah Papua memilikki tinggi gelombang yang potensial.

\section{TINJAUAN PUSTAKA}

Energi listrik dari tenaga gelombang air laut dalam pengembangan di Denmark melalui Wave Star Energy Machine. Wave Star Energy Machine merupakan teknologi pembaharuan energi yang digagas oleh Niels dan Keld Hansen pada tahun 2000 di Hanstholm, Denmark. Niels dan Keld membuat sebuah teknologi pembangkit tenaga listrik dalam bentuk sebuah platform yang memiliki 20 floats dengan 10 floats pada masing-masing sisi platform. Floats ini berbahan Fiberglass Reinforced Plastic (FRP) dengan diameter sebesar $5 \mathrm{~m}$ dan ditopang oleh lengan sepanjang $10 \mathrm{~m}$. Lengan pada floats dapat digerakan secara otomatis dengan cara yang sama seperti proses gerakan pada crane. Rata-rata berat dari satu buah floats adalah sebesar 80 ton.

Wave Star Energy Machine bertujuan untuk menghasilkan energi listrik yang didapat dengan mengkonversi energi kinetik dari gelombang. Gelombang ditangkap melalui floats yang bergerak mengapung mengikuti gelombang secara vertikal dan rotasional. Gerakan ini memompa sebuah pompa hidrolik yang menggerakkan generator dan menghasilkan tenaga listrik. Setelah itu, energi listrik dialiri menuju inverter untuk diubah arusnya dari AC menjadi DC supaya bisa disimpan di baterai. Setelah disimpan di baterai, energi listrik dialiri kembali ke inverter dan energinya diubah kembali dari DC ke AC supaya bisa disalurkan ke daratan [1] .

Proses desain merupakan proses yang dilakukan secara berulang-ulang hingga menghasilkan suatu desain yang sesuai dengan apa yang diinginkan. Dalam proses desain pembangunan kapal baru terdapat beberapa tahap desain, yaitu antara lain [2]:

1. Concept Design

2. Preliminary Design

3. Contract Design 


\section{Detail Design}

\section{METODOLOGI PENELITIAN}

Tahap pengerjaan Studi ini digambarkan melalui diagram alir berikut:

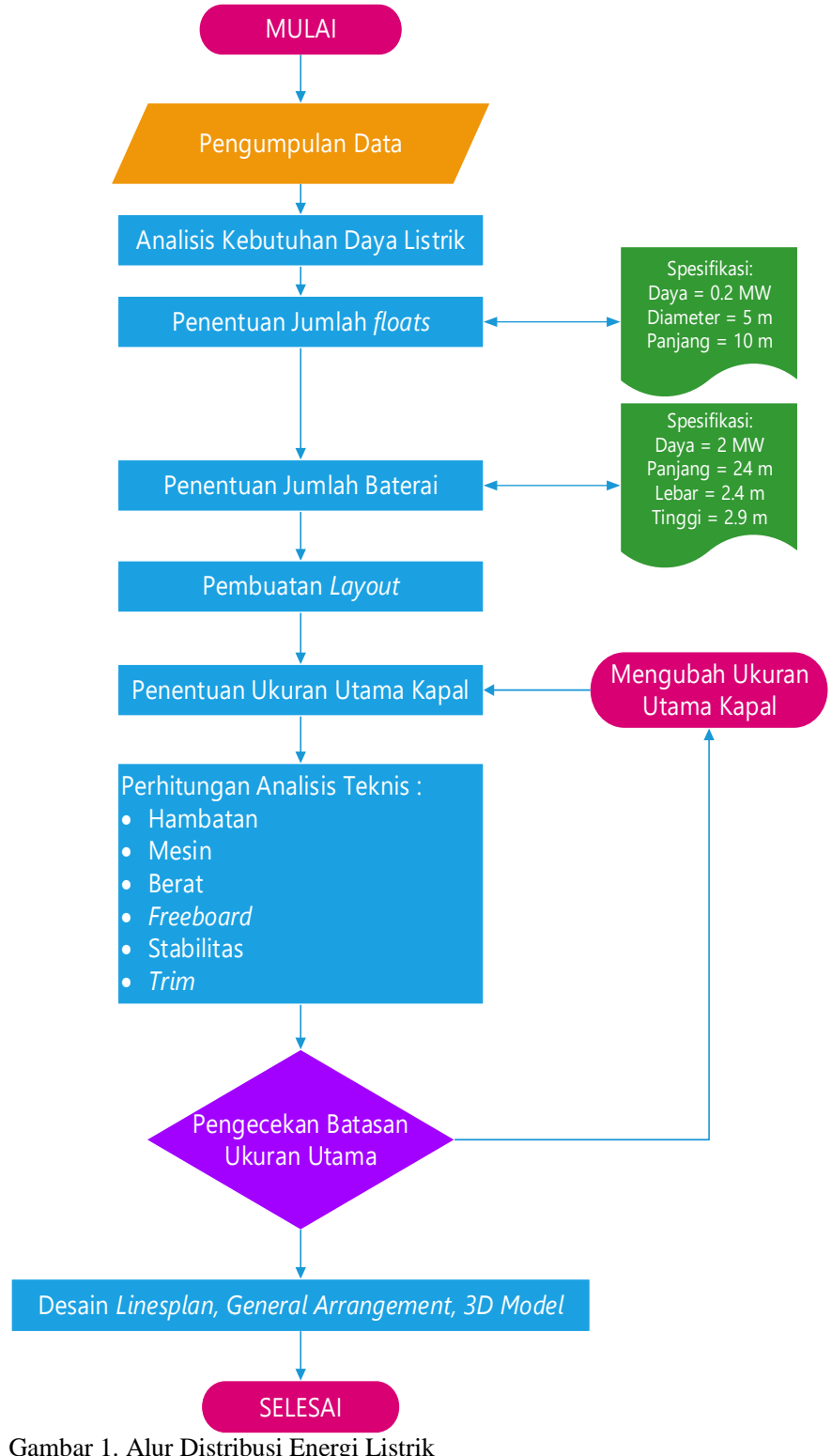

\section{TINJAUAN WILAYAH}

Pulau Papua adalah pulau terluas kedua di dunia dan merupakan yang terluas di Indonesia. Total Area pada wilayah Papua adalah $808.105 \mathrm{~km} 2$. Batas utara pada provinsi ini adalah Samudera Pasifik, batas barat adalah Kepulauan Maluku, batas timur adalah Papua Nugini dan batas selatan adalah Samudera Hindia, Laut Arafuru, Teluk Carpentaria dan Australia. Pada tahun 2016, Papua menjadi provinsi di Indonesia dengan rasio elektrifitas terendah, yaitu dibawah $70 \%$ [3].

Kota yang dijadikan studi kasus dalam penggunaan kapal pembangkit listrik adalah Kota Serui. Serui adalah sebuah Kota di Papua. Merupakan ibu kota dari Kabupaten Kepulauan
Yapen yang terletak di distrik Yapen Selatan. Mempunyai jumlah penduduk 24.290 jiwa (2000). Total kebutuhan listrik di Kota Serui adalah 8.4 MW dan baru terpenuhi sebesar 5.6 MW (66.67\%)[4].

Kecepatan angin sekitar 3-15 knot dan tinggi signifikan gelombangnya $1.50-2.00$ meter [4].

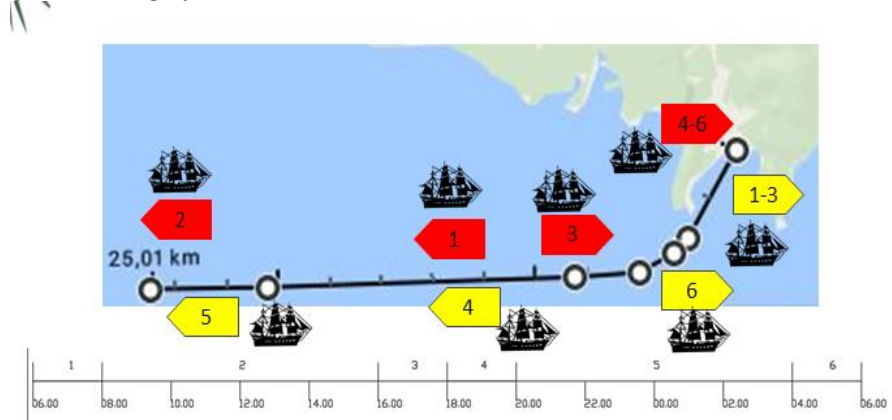

Gambar 2. Alur Distribusi Energi Listrik

Dalam perencanaan rute Kapal dibutuhkan dua kapal untuk mengisi energi listrik, masing-masing mengisi energi sebesar 36 MWh untuk penggunaan selama 12.5 jam. Proses berlabuhnya Kapal diabaikan pada perhitungan waktu pelayaran Kapal.

Tabel 1.

Kegiatan Kapal I

\begin{tabular}{rrr}
\hline \hline Periode & Waktu (jam) & Kegiatan Kapal I \\
\hline 1. & $06.00-08.00$ & Kapal berangkat ke laut \\
2. & $08.00-16.00$ & Pengisian energi listrik \\
3. & $16.00-18.00$ & Perjalanan kembali ke Kota Serui \\
4. & $18.00-20.00$ & Penyaluran Energi Listrik \\
5. & $20.00-04.00$ & Penyaluran Energi Listrik \\
6. & $04.00-06.00$ & Penyaluran Energi Listrik \\
\hline \hline Periode & Waktu (jam) & Kegiatan Kapal II \\
\hline 1. & $06.00-08.00$ & Penyaluran Energi Listrik \\
2. & $08.00-16.00$ & Penyaluran Energi Listrik \\
3. & $16.00-18.00$ & Penyaluran Energi Listrik \\
4. & $18.00-20.00$ & Kapal berangkat ke laut \\
5. & $20.00-04.00$ & Pengisian energi listrik \\
\hline \hline
\end{tabular}

\section{ANALISIS TEKNIS}

A. Desain Awal

Dalam menentukan desain awal dari Kapal ada beberapa hal yang perlu diperhatikan sebagai berikut:

1. Kebutuhan listrik di Kota Serui (2.8 MW) 
2. Jumlah floats yang dibutuhkan (20)

3. Ukuran floats yang dibutuhkan $(\mathrm{d}=5 \mathrm{~m})$

4. Jumlah baterai yang dibutuhkan (18)

5. Ukuran baterai yang dibutuhkan $\left(97.44 \mathrm{~m}^{3}\right)$

6. Kedalaman terdangkal pada terminal tujuan

Sehingga didapat desain awal Kapal seperti pada gambar berikut ini:

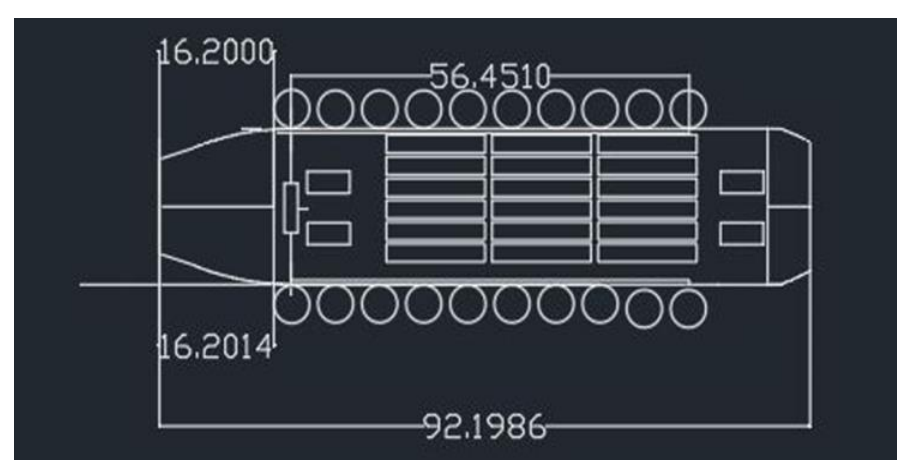

Gambar 3. Desain Awal Kapal

Lwl : $95.888 \mathrm{~m}$

Lpp : $92.2 \mathrm{~m}$

B $: 18.5 \mathrm{~m}$

$\mathrm{H} \quad: 5.2 \mathrm{~m}$

$\mathrm{L} / \mathrm{B}=4.984 \rightarrow 3.5<\mathrm{L} / \mathrm{B}<10$

$\mathrm{B} / \mathrm{T}=4.933 \rightarrow 1.8<\mathrm{B} / \mathrm{T}<5$

$\mathrm{L} / \mathrm{T}=24.587 \rightarrow 10<\mathrm{L} / \mathrm{T}<30$

$\mathrm{T} / \mathrm{H}=0.721 \rightarrow 0.7-0.8$

\section{B. Perhitungan Awal}

Dari desain awal kemudian dihitung perhitunganperhitungan awal yang terdiri dari:

1) Perbandingan ukuran kapal;

2) Froude Number;

3) Block Coefficient;

4) Midship Coefficient;

5) Prismatic Coefficient;

6) Waterplane Coefficient;

7) Longitudinal Centre of Buoyancy;

8) Displacement;

\section{Hambatan}

Pada Studi ini perhitungan hambatan Kapal menggunakan metode Holtrop dengan hasil akhir sebagai berikut:

$$
\mathrm{R}_{\mathrm{T}}=108.21 \mathrm{kN}
$$

Setelah nilai hambatan total didapatkan, maka dapat dilakukan perhitungan daya yang dibutuhkan untuk sistem propulsi kapal, yaitu sebesar 1486.52 kiloWatt $(\mathrm{kW})$.

\section{Lightweight Tonnage}

Lightweight Tonnage (LWT) merupakan berat kapal kosong yang terdiri dari berat baja dan konstruksi kapal, berat sistem permesinan kapal dan berat perlengkapan kapal. Dari hasil perhitungan LWT didapatkan LWT kapal sebesar 1601,747 ton.

\section{E. Deadweight Tonnage}

Deadweight Tonnage (DWT) merupakan berat maksimum muatan pada kapal yang dapat diangkut yang terdiri dari berat muatan $(L N G)$ dan berat consumable (Fresh Water, Fuel Oil, Lubricating Oil). Dari hasil perhitungan DWT didapatkan DWT kapal sebesar 3086.38 ton.

\section{F. Freeboard}

Perhitungan freeboard mengacu pada International Convention of Load Lines (ICLL) tahun 1969. Freeboard Kapal sesungguhnya adalah sebesar $1.45 \mathrm{~m}$ dan freeboard minimum sebesar $0,7 \mathrm{~m}$.

\section{G. Stabilitas}

Analisis stabilitas digunakan untuk mengetahui keseimbangan kapal secara melintang pada beberapa kondisi pemuatan (loadcases). Pada perhitungan stabilitas ini dilakukan dengan menggunakan software Maxsurf Stability Enterprise Educational Version. Kriteria stabilitas yang digunakan adalah kriteria stabilitas kapal umum yang mengacu pada Intact Stability (IS) Code Reg. III/3. 1. Berikut merupakan hasil running pada setiap loadcase:

Tabel 3.

Rekapitulasi Hasil Perhitungan Stabilitas

\begin{tabular}{|c|c|c|c|c|}
\hline \multirow{2}{*}{ Criteria } & \multirow{2}{*}{ Value } & \multicolumn{3}{|c|}{ Actual } \\
\hline & & LC1 & $\mathrm{LC} 2$ & LC3 \\
\hline $\begin{array}{l}\text { Area } 0 \text { to } \\
30(>=)\end{array}$ & $\geq 3.151$ & 52.786 & 47.483 & 59.330 \\
\hline $\begin{array}{l}\text { Area } 0 \text { to } \\
40(>=)\end{array}$ & $\geq 5.157$ & 80.758 & 71.117 & 92.130 \\
\hline $\begin{array}{c}\text { Area } 30 \text { to } \\
40(>=)\end{array}$ & $\geq 1.719$ & 27.972 & 24.634 & 32.801 \\
\hline $\begin{array}{c}\text { Max GZ at } \\
30(>=)\end{array}$ & $\geq 0.2$ & 2.813 & 2.489 & 3.352 \\
\hline $\begin{array}{l}\text { Angle of } \\
\text { Max GZ }\end{array}$ & $\geq 25$ & 37.3 & 39.1 & 42.7 \\
\hline Initial GMt & $\geq 0.15$ & 8.056 & 7.696 & 8.882 \\
\hline
\end{tabular}

\section{H. Trim}

Trim merupakan kondisi keseimbangan kapal secara memanjang. Trim terjadi karena perbedaan letak titik LCB dan LCG Kapal sehingga menyebabkan perbedaan sarat pada bagian haluan dan buritan kapal. Perhitungan trim dilakukan dengan menggunakan software Maxsurf Stability Enterprise Educational Version. Kriteria stabilitas yang digunakan adalah kriteria trim mengacu pada SOLAS Reg. II/7, dimana kondisi trim maksimum yang diizinkan adalah sebesar 0,5\% Lpp. Berikut merupakan hasil running pada setiap loadcase:

Tabel 4. Hasil Perhitungan Trim

\begin{tabular}{ccc}
\hline \hline & & \\
Loadcases & $0,5 \%$ Lpp $(\mathrm{m})$ & Value $(\mathrm{m})$ \\
& & \\
\hline LC 1 & 0.461 & 0.027 \\
LC 2 & 0.461 & 0.083 \\
LC 3 & 0.461 & 0.009
\end{tabular}




\section{Lines Plan}

Rencana garis merupakan gambaran bentuk lambung kapal yang diproyeksikan menjadi tiga sudut pandang yaitu sudut pandang depan, samping dan atas. Langkah awal adalah pembuatan model. Kemudian dilakukan perubahan pada beberapa elemen antara lain ukuran utama, grid spacing dan zero-point sesuai dengan kapal yang akan didesain.

Untuk mendapatkan kriteria displacement yang sesuai dengan perhitungan dilakukan penyuntingan manual dengan memindahkan control point pada tempat yang sesuai. Control point berpengaruh pada lekuk lambung kapal di bawah air sehingga mengubah displacement.

\section{GENERAL ARRANGEMENT}

Rencana umum merupakan perencanaan ruangan di dalam kapal yang dibutuhkan sesuai dengan fungsi dan perlengkapan kapal. Pada pembuatan rencana umum untuk kapal jenis ini disesuaikan dengan peralatan yang dibutuhkan. Secara umum, rencana umum digambarkan pada tiga sudut pandang yaitu tampak depan, tampak samping dan tampak atas kapal. Gambar Rencana Umum dapat dilihat pada Gambar 5.

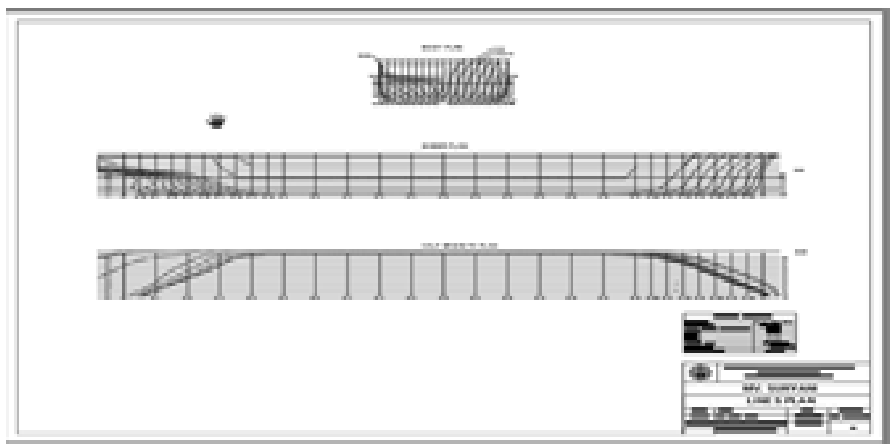

Gambar 4. Lines Plan

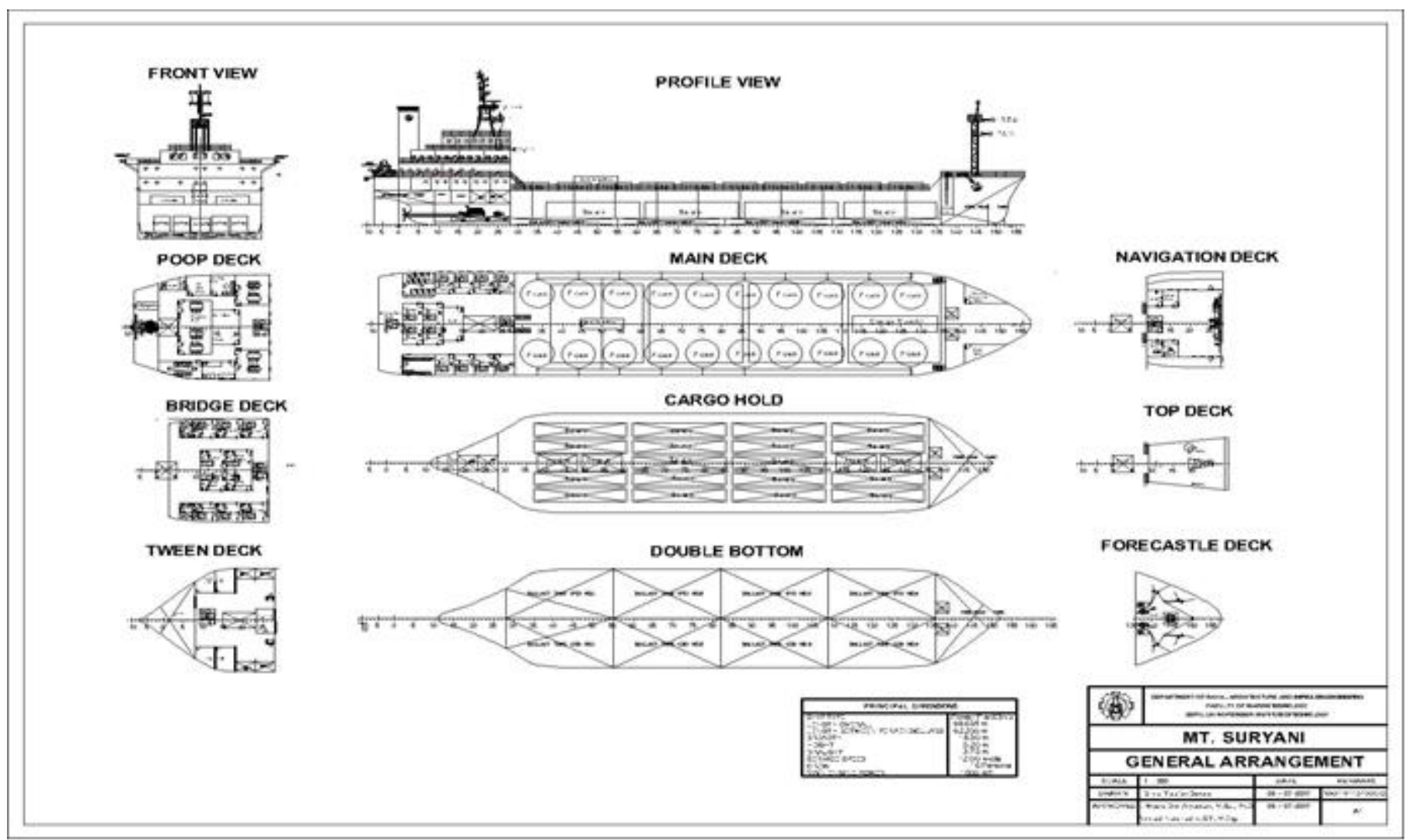

Gambar 5. General Arrangement. 


\section{A. Pemodelan 3 Dimensi Kapal}

Pemodelan 3 Dimensi (3D) kapal ini harus sesuai dengan ukuran utama kapal dengan bentuk lambung yang proporsional terhadap desain lambung kapal. Hasil pemodelan 3D Kapal dapat dilihat pada Gambar. 6. Hingga Gambar. 8.

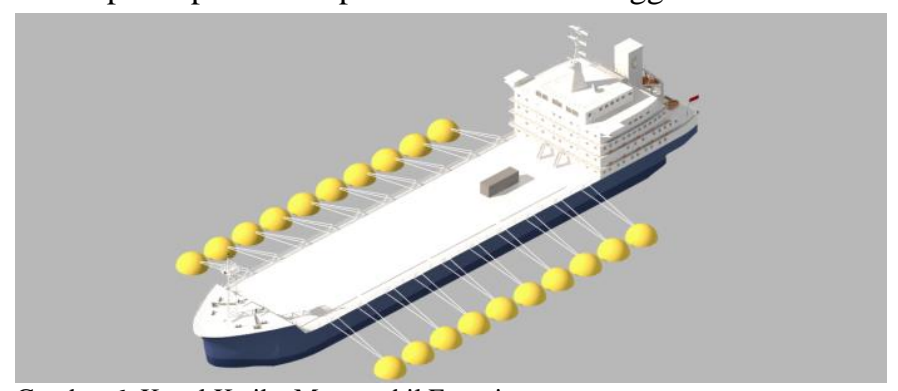

Gambar 6. Kapal Ketika Mengambil Energi

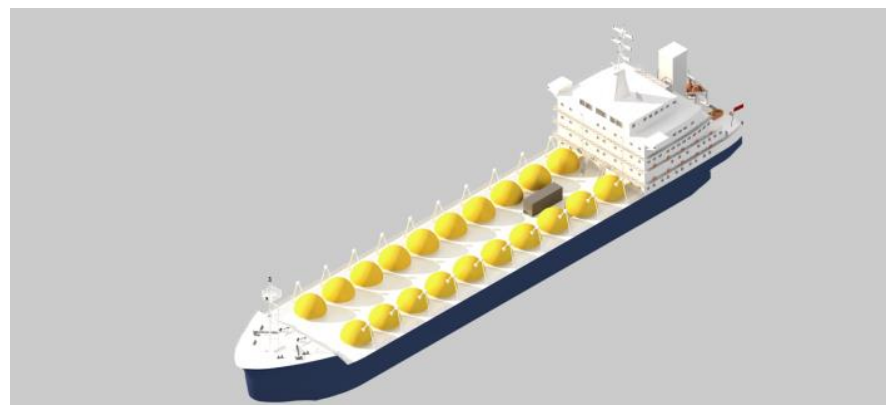

Gambar 7. Kapal Ketika Berlayar

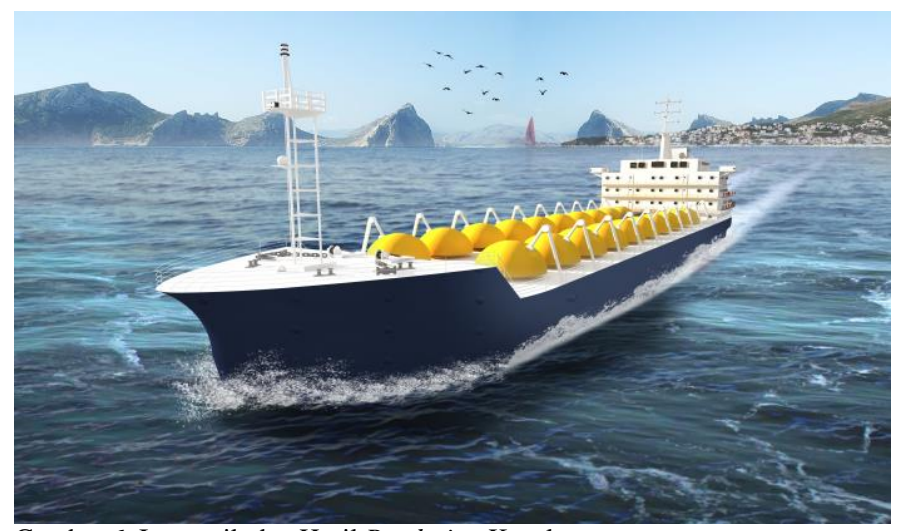

Gambar 6. Isometrik dan Hasil Rendering Kapal

\section{ANALISIS EKONOMIS}

\section{A. Biaya Pembangunan}

Perhitungan (estimasi) biaya pembangunan kapal dilakukan dengan menghitung biaya baja dan elektroda, biaya permesinan, biaya perlengkapan kapal dan biaya keuntungan galangan. Sehingga didapat biaya pembangunan kapal sebesar Rp 36,806,035,000. (Tiga Puluh Enam Miliar Delapan Ratus Enam Juta Tiga Puluh Lima Ribu Rupiah).

\section{B. Break Even Point (BEP)}

Perhitungan BEP didapatkan dari hasil perhitungan biaya pembangunan dan biaya operasional kapal dibandingkan dengan pendapatan operasional dengan harga jual listrik sebesar Rp 1.467,28 per kWh sehingga didapatkan BEP pada bulan ke 58 (Lima Puluh Delapan) dengan estimasi keuntungan bersih sebesar Rp 644,337,000 (Enam Ratus Empat Puluh Empat Juta Tiga Ratus Tiga Puluh Tujuh Ribu Rupiah).

\section{KESIMPULAN}

Berdasarkan uraian dari Studi ini, dapat diambil kesimpulan sebagai berikut:

1. Dari keseluruhan wilayah Kota Serui, hanya $66,67 \%$ (5,6 MW dari 8,4 MW) yang sudah teraliri listrik dan dibutuhkan dua kapal untuk memenuhi seluruh kebutuhan listrik di Kota Serui.

2. Ukuran utama kapal adalah Lpp: 92,2 m; B: 18,5 m; H: 5,2 $\mathrm{m}$ dan $\mathrm{T}: 3,75 \mathrm{~m}$.

3. Daya listrik yang dihasilkan oleh masing-masing kapal pembangkit listrik adalah $36 \mathrm{MWh}$ dengan floats berjumlah 20, baterai berjumlah 18 dan dapat digunakan selama 12.5 jam.

4. Gambar Lines Plan, General Arrangement, dan 3D telah memenuhi aspek yang ada dalam perencanaan kapal, dan sesuai dengan peraturan yang ada, hasil dapat dilihat pada Lampiran.

\section{DAFTAR PUSTAKA}

[1] W. Energy, "Wavestar Energy Concept," 2016. [Online]. Available: http://www.wavestarenergy.com.

[2] R. Taggart, Ship Design and Construction Chapter 5. SNAME, 1980.

[3] Wikipedia, "Wikipedia," 2017. [Online]. Available: http://www.wikipedia.org/Papua.

[4] B. M. K. dan Geofisika, "Prakiraan Tinggi Gelombang Satu Tahun Kedepan," $2017 . \quad$ [Online]. Available: http://maritim.bmkg.go.id/prakiraan/satu_tahun_kedepan. 